\title{
Forthcoming articles
}

Direct Democracy and Public Policy Making. Uwe Wagschal, Political Science, University of Heidelberg.

From the Positive to the Regulatory State: Causes and Consequences of Changes in the Mode of Governance. Giandomenico Majone, Public Policy, European University Institute, Florence.

International Games with National Rules: Regulation Shapes Competition in 'Global Markets'. Steven K. Vogel, Government, Harvard University.

Starting Over in Pensions: The Challenges Facing Central and Eastern Europe. Robert Holzmann, Economists, World Bank and University of Saarland.

Negotiated Risks: Employers and the Development of Unemployment Insurance. Isabela Mares, Centre for European Studies, Harvard University. 


\section{Recent articles:}

Policy design, Bureaucratic Incentives, and Public Management: The Case of Child Support Enforcement

Lael R. Keiser and Kenneth J. Meier

Hollowing the Infrastructure: Revolving Loan Programs and Network Dynamics in the American States

Laurence J. O'Toole Jr.

Accountability in Human Services Collaboratives-For What? and to Whom?

Eugene Bardach and Cara Lesser

The Administrative Dispute Resolution Act of 1990: How do We Evaluate its Success?

Lisa B. Bingham and Charles R. Wise

Regulatory Privatization: A Case Study William T. Gormley Jr.

\section{H. George Frederickson} EDITOR

University of Kansas

\section{Dedicated to}

artoancing

knozuledge of public

alministration

through research and

theoretical analysis.

The journal

publishes reports of

empirical zoork,

incluling both

quantitatioe and

qualitation areas of

research.

\section{JOURNAL L PUBLIC ADMINISTRATION Research and Theory}

\section{Published Quarterly}

\section{Subscription Rates:}

Individuals: $\$ 48 / y r ; \$ 88 / 2 y r s ; \$ 120 / 3 y r s$

Institutions: $\$ 104 / y r ; \$ 192 / 2 y r s ; \$ 264 / 3 y r s$

Foreign surface mail add $\$ 32 / y r$

Foreign airmail add $\$ 48 / y r$

(Rates subject to change annually)

Visit us on the web at

http://MWW.TRANSACTIONPUB.COM

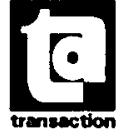

TRANBACTION PUBLISHERS DEPARTMENT 2097

RUTGERS-THE STATE UNIVERSITY

NEW BRUNSWICK, NEW JERSEY 08903 


\section{Policy \& Politics}

Policy \& Politics is a multi-disciplinary journal concerned with the origins, impact and evaluation of public policy across a range of areas, including health, housing, governance, labour markets, education, the environment, urban policy and community care.

Recent articles include:

Sarah Payne, Psychiatric care in the community: does it fail young men?; Christian Toft, Constitutional choice, multi-level government and social security systems in Great Britain, Germany and Denmark; Francis G. Castles and Christopher Pierson, A new convergence? Recent policy developments in the United Kingdom, Australia and New Zealand.

\section{Special issue January 1997}

Regionalism in England: current trends and future prospects

Edited jointly by Peter John and Alan Whitehead, this issue includes articles on:

- Business partnerships and regional government (Coulson)

- The government offices for the English regions (Mawson and Spencer)

- Regionalisation, regional institutions and economic development (Evans and Harding)

\section{Leading the field in policy studies for 25 years}

Editor: Randall Smith, University of Bristol.

Abstracts Editor: Derek Howes, University of Bristol.

Policy \& Politics, volume 25, 1997 (4 issues):

\begin{tabular}{|l|l|l|}
\hline & UK/Europe & Rest of the world \\
\hline Institutions & 687 & 695 \\
\hline Individuals & 639 & 642 \\
\hline
\end{tabular}

Published quarterly in January, April, July and October.

Subscriptions to Pollcy \& Polltics

D I would like to subscribe to Policy \& Politics and enclose payment. (Cheques should be made payable to University of Bristol)

a Please send me a pro forma invoice for:

$$
\begin{aligned}
& \text { D Individuals } \\
& \text { D Institutions }
\end{aligned}
$$

a Please send me a free inspection copy of Policy \& Politics

Name:

Organisation

Address:

Return to: The Policy Press, University of Bristol, Rodney Lodge, Grange Road, Bristol BS8 4EA

Tel: +44(0) 1179741117 ,

Fax: $+44(0) 1179737308$

E-mail: tpp-pp@bris.ac.uk

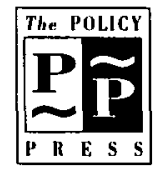

Policy \& Politics is published by The Policy Press on behalf of the School for Policy Studies, University of Bristol.

ISSN 0305-5736 


\section{Review of International Studies}

\section{Editor}

Paul Taylor

London School of Economics

Established in 1974 as the flagship journal of the British International Studies Association, Review of International Studies serves the needs of scholars in politics, law, history and all other areas of social science in the international arena.

\section{Wide-ranging}

Review of International Studies is a journal which no library on international relations can be without. Its scope is wide-ranging both in terms of subject matter and method. It covers all topics from international organization and intercultural communication to political economy and war cultures. It is receptive to new methodologies and draws on the expertise of other disciplines, such as sociology and psychology, to throw light on the study of international relations. Review of International Studies takes a strong interdisciplinary perspective.

\section{Review of}

\section{International Studies...}

- contains articles of lasting importance

- is genuinely interdisciplinary

- is committed to serious scholarship

- has contributors from round the world
- is a journal for professionals

\section{Subscription}

\section{Information}

Review of International Studies, Volume 23, 1997 is published quarterly in January. Aprih, July and October. 164 for institutions; $£ 43$ for individuals; $£ 37$ for APSA members; prices include delivery by air. Special arrangements exist for BISA members. ISSN 0260-2105.

\section{Take a closer look} | FREE!

$\mathrm{I} \square$ Please send me further

I information/a free sample copy of | Review of International Studies

I Name

Address

1

1

| Please send this coupon to: Journals Marketing Department., Cambridge

University Press, "FREEPOST, The

Edinburgh Building, Cambridge, CB2 IBR, UK.

Tel: $+44(0) 1223325806$

Fax: +44 (0) 1223315052

| Email: journals_marketing@cup.cam.ac.uk ("no postage stamp necessary if posted in UK) In USA, Canada \& Mexico, write to:

Cambridge University Press, 40 West 20th Street, New York, NY 10011-4211, USA.

Tel: 9149379600 x154 Fax: 9159374712

Email: journals_marketing@cup.org 


\section{Studies in American Political Development}

\section{Editors}

Karen Orren, University of California, Los Angeles

Stephen Skowronek, Yale University

Studies in American Political Development publishes high quality scholarship covering American political change and institutional development from a historical perspective. Articles focus on government institutions and their social, economic and cultural environment. The journal features in-depth original articles, which allow scholars to elaborate on the complex parterns of state-society relations. These longer articles also encourage an interdisciplinary approach - tying in relevant issues and related themes. In addition, SAPD recognizes the importance of comparative politics to the study of American institutions.

\section{Readership}

Contributors and readers of Studies in American Political Development come from: • American Government • Political History • Comparative Politics • Economic History • Legal Studies • Sociology

\section{Subscription Information}

Volume 11 in 1997: Spring and Autumn. $\$ 40$ for institutions and $£ 20$ for individuals; prices include delivery by air. ISSN 0898-588X.

\section{Further Information}

| $\square$ Please send me a FREE sample copy of Studies in American Political Development

$\square$ Please send me further informtion Name

Address 1 1 I

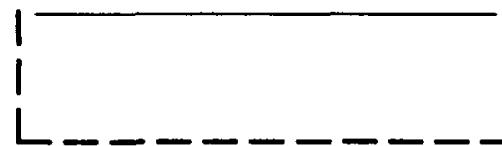

Send this coupon to: Journals Marketing Department, Cambridge University Press, The Edinburgh Building, Cambridge CB2 2RU, UK.

Tel: $+44(0) 1223325969$

Fax: $+44(0) 1223315052$

Email: journals_marketing@cup.cam.2c.uk In USA, Canada \& Mexico send to: Cambridge University Press, 40 West 20th Street, New York, NY 10011-4211, USA Tel: $9149379600 \times 154$

Fax: 9149374712

Email: journals_marketing@cup.org

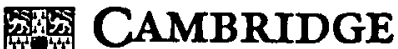
UNIVERSITY PRESS 


\section{NOTES TO CONTRIBUTORS}

\section{GLIDELINES}

The distinctive readership of the Journal, cutting across academic disciplines and national boundaries, makes the following points of particulat importance to contributors.

*Whatever the specific subject matter, the relevane of conclusions to a broad understanding of policvmaking should be made explicit.

* Whatever the national setting, the extent to which conclusions are generalizable to many nations should be explicitly discussed.

*Each article should show an awareness of the constraints that public institutions place upon policy making.

*Jargon should be avoided; technical terms not widely understood should be clearly defined: and the conclusions of statistical analyses should be set out in prose, as well as being supported br quantitative information in tables, footnotes and text as appropriate.

\section{PREPARATION OF MANUSCRIPT}

The entire manuscript, including footnotes and references, should be typed double-spaced on one side onle of $\mathrm{A}_{4}$ size paper, with a left-hand margin of at least $1 \frac{1}{4}$ inches $\left(4^{\frac{1}{2}} \mathrm{~cm}\right)$. Manuseript pages should be numbered consecutively.

The title of the article and the author's name and address should be trped on a separate page at the beginning of the article.

The second page should contain an abstract of not more than 150 words and the title of the article, but not the author's name

Tables and figures should be numbered consecutivels in separate series. Fach table or figure should be typed or drawn on a separate sheet. Every table or figure should have a title or caption and at least one reference in the text to indicate its approximate location.

When an article has been accepted for publication. the author is strongly encouraged to send a cops of the final version on computer disk (Apple Macintosh or IBM compatible PC) together with the hard copy typescript, giving details of the wordprocessing software used (Microsoft Word, Word or Word Perfect). However, the publisher reserves the right to typeset material by conventional means if an atuthor's disk proves unsatisfactory

\section{STYLE}

Spelling, capitalization and punctuation should be consistent within each article. Detailed advice on all matters of stsle is contained in Judith Butcher's book. Copy-Editing, Cambridge University Press (1992)

Headings of not more than two grades should be used and they should be typed on separate lines.

Numbered footnotes should be aroided; citation of references in the text is the norm. If there are a few points that require discussion in the article but not in the body of the text. numbered footnotes mas be used. Ther may also be useful for technical details, e.g. statistical points that would interrupt the flow of the text. Numbered footnotes should be typed consecutively, doublespaced, at the end of the paper, starting on a new page.

References to publications should be placed in the text. Examples of correct styling for bibliographie citation where the author's name is mentioned in the text are Alford (1975), Biller $\left(197^{6}, 13^{6-7}\right)$, May and Wildavsky (1978). Ostrom, Parks and Whitaker $(1978)$ and subsequently Ostrom et al. (1978).

At the end of the paper, all references should be consolidated in a single alphabetical list starting on a new page. Authors are particularly requested to verify that each text reference appears in the list, and vice versa. In addition to author(s) surname and first name (s) or initial(s), and the title of the book or article, references to books should always include the city of publication and publisher, and for journal articles the volume and part number. For example:

Alford, R. (1975) Health Care Politics. Chicago: University of Chicago Press.

Biller, R. $(19-6)$ On tolerating policy and organizational termination: some design considerations, Policy Sciences. 7, 2, 133-149.

Campbell, D. (1971) Reforms as experiments. In F. Caro (ed.), Readings in Evaluation Research. New York: Russell Sage.

May.J and A. Wildarsky (eds.) (1978) The Policy Crcle. Beverly Hills: Sage.

\section{SUBMISSION}

Please submit the original manuscript plus three copies to: Professor Richard Rose, Journal of Public Polico. Cientre for the Study of Public Polics, University of Strathelyde, Livingstone Tower, Glasgow, Gi 1 xH, Scotland.

\section{COPY-EDITING AND PROOF- READING}

The editor and publishers reserve the right to copv-edit and proof-read all items accepted for publication. Authors will review their copyedited manuscripts only if substantial changes have been made. Manuscripts which do not conform to the requirements about style and format may be returned for retypying.

Page proofs of articles will be sent to authors for correction of typographical errors only. Authors must notify the editorial office of any corrections within one week of receipt or approval will be assumed.

Submission of an article or other item implies that it has not been published or accepted for publication elsewhere. Authors are responsible for obtaining written permission to publish material for which they do not own the copyright. Contributors of material accepted for publication will be asked to assign their copyrights to Cambridge University Press.

Fifty offprints will be supplied without charge to the (first) author of each article. Additional copies mav be purchased if ordered at proof stage. 


\section{Journal of Public Policy}

VOLUME 17 PART 1 January-April 1997

\section{ARTICLES}

1 JOE Wallis

Conspiracy and The Policy Process: A Case Study of the New Zealand Experiment

31 Alan Siaroff and Clement Lee

The State and Industrial Followers: Japanese Versus French Computer Strategy, 1960 s-1980s

63 John N. ANENE

Military Administrative Behavior and Democratization: Civilian Cabinet Appointments in Military Regimes in Sub-Saharan Africa

81 Stephen MartiN and Keith Harthey

Comparing Profitability in the Public Utilities, Defence and Pharmaceuticals

107 TARYN ROUnds PARRY

Decentralization and Privatization: Education Policy in Chile

\section{BOOK REVIEWS}

Fiona Hayes-Renshaw and Helen Wallace, The Council of Ministers (Yves Meny) 135; Edward C. Page, People tho Run Europe (J. Blondel) 136-137; Avner Offer, ed., In Pursuit of the Quality of Life (Steffan Mau) $137^{-1} 3^{8}$

Printed in the United Kingdom by The Universities Press (Belfast) Ltd 